\title{
Activity of Engineered Nano-Semiconductor Oxides against Gram Positive and Gram Negative Bacteria
}

\author{
Naresh Kumar Sharma, Balakrishnan A, Karthika A, Thirumalai K, Swaminathan M
}

\begin{abstract}
Antibacterial activities of semiconductor oxides such as $\mathrm{ZnO}$ and $\mathrm{TiO}_{2}$ have induced research on the design of engineered nanoparticles (ENPs) for the last few decades. We had synthesized modified $\mathrm{ZnO}$ and $\mathrm{TiO}_{2}$ using rare earth salts and analyzed their antibacterial activities against Bacillus brevis. (Gram positive) and E. coli (Gram negative) by modified well diffusion method. Among the seventeen nanoparticles studied, Ag- $\mathrm{TiO}_{2}$ showed highest antibacterial activity against Gram positive and Gram negative bacteria. Antibacterial activities of $\mathrm{Ni}-\mathrm{Ag}-\mathrm{TiO}_{2}, \mathrm{ZnO}, \mathrm{Eu}_{2} \mathrm{O}_{3}-\mathrm{ZnO}, \mathrm{DyMoO}_{4} \mathrm{ZnO}$, $\mathrm{GdMoO}_{4}-\mathrm{ZnO}, \mathrm{DyVO}_{4}-\mathrm{ZnO}, \mathrm{GdVO}_{4}-\mathrm{ZnO}$ and $\mathrm{HoVO}_{4}-\mathrm{ZnO}$ were found to be significant. From the microbial plating experiments it was shown that the synthesized nano materials show a wide spectrum of antibacterial activities performed against Bacillus brevis, and $E$. coli. In this study we help to understand the influence of the engineered nanoparticles (ENPs) against microbes, as these ENPs finds wide applications in medicine, water treatment, in food industry as anti-coating agents.
\end{abstract}

Keywords : : Engineered nano particles (ENPs), Bacillus brevis, E. coli, Antibacterial activity.

\section{INTRODUCTION}

Application of nano materials ranging from environmental care to human health are highly practiced (Sahoo et al., 2007; Koo et al., 2005; Lopez et al., 2012) Nanoparticles are being viewed as fundamental building blocks of nanotechnology. Engineered nanoparticles (ENPs) have great potential in achieving specific processes and selectivity of conventional materials. It has enormous applications in the field of biological and pharmaceutical engineering (Brigger et al., 2002; Wu et al., 2003). The influence of engineered nano materials on microbes can lead to two different avenue of studies (i) anti-coating agents for applications in medicinal instruments, water treatment reactors, food packaging etc., (ii) the survival and selection of natural microbes on disposal of these nano material after their usage on to the environment (Pattan and Kaul 2014; Swaminathan and Naresh 2017). $\mathrm{TiO}_{2}$ and $\mathrm{ZnO}$ are well known metal oxide semiconductors and are studied

Revised Manuscript Received on December 05, 2019

* Correspondence Author

Naresh K Sharma*, Biotechnology, Kalasalingam Academy of Research and Education, Tamilnadu, INDIA.

Balakrishnan A, Summer Student's Visiting Internship Program 2017, Kalasalingam Academy of Research and Education, Tamilnadu, INDIA

Karthika A, Biotechnology, Kalasalingam Academy of Research and Education, Tamilnadu, INDIA.

Thirumalai K, Department of Chemistry, Annamalai University, Tamilnadu, INDIA.

Swaminanthan M, Chemistry, Kalasalingam Academy of Research and Education, Tamilnadu, INDIA. extensively for their chemical stability and efficient photocatalytic characteristics. The special electronic, chemical and physical properties of metal oxide nanoparticles

(especially $\mathrm{TiO}_{2}$ and $\mathrm{ZnO}$ ) have attracted considerable attention (Wahab et al., 2010).

Specially formulated metal oxide nanoparticles have high antibacterial activity (Stoimenov et al., 2002; Sarah et al., 2013; Rajiv et al., 2013; Xiaoyan et al., 2012; Yanjing et al., 2013). The synthesized $\mathrm{TiO}_{2} / \mathrm{ZnO}$ composite powders were highly effective against $E$. coli (Stoyanova et al., 2013). Jaskova et al. (2013) reported that Escherichia coli and Staphylococcus aureus were effectively static even at the low concentration of nano- $\mathrm{ZnO}$ particles. Nanoparticles are proven to be a very good option for antimicrobial additives because of their size which is quite smaller than the size of the cells such that it can easily pass through the membrane (Travan et al., 2011) The nanoparticles interact with bacterial surface or with the bacterial core where it enters inside the cell and subsequently exhibits distinct bacterial mechanisms which leads to either the inactivation or bacterial death (Seil and Webster, 2012).There is an ever increasing demand in developing novel antibacterial agents against bacteria such as Staphylococcus aureus, Pseudomonas aeruginosa, E. coli, , Enterococcus faecalis and Campylobacter, Clostridumper fringe which are well-known pathogens. Synthesis of nano $\mathrm{Ag}-\mathrm{TiO}_{2}$ was reported first time from our group in 2004 for the degradation of direct azo dyes (Sobana et al., 2006). In continuation we prepared modified $\mathrm{TiO}_{2}$ and $\mathrm{ZnO}$ for enhancing the efficiency of these oxides. Recently we reported the synthesis of rare earth oxides loaded $\mathrm{ZnO}$ for multiple applications (Thirumalai et al., 2017). In the present work, we investigated the antibacterial effects of seventeen nanoparticles such as $\mathrm{ZnO}$ (Zinc oxide) $\mathrm{TiO}_{2}$ (Titanium dioxide), AGT $\left(\mathrm{Ag} / \mathrm{TiO}_{2}\right)$, CAT $\left(\mathrm{Cd} / \mathrm{Ag} / \mathrm{TiO}_{2}\right)$, NAT $\left(\mathrm{Ni} / \mathrm{Ag} / \mathrm{TiO}_{2}\right)$, TUB $\left(\right.$ Bare $\left.\mathrm{Eu}_{2} \mathrm{O}_{3}\right)$, TGB $\left(\right.$ Bare $\left.\mathrm{Gd}_{2} \mathrm{O}_{3}\right)$, TUZ ( $\mathrm{Eu}_{2} \mathrm{O}_{3} / \mathrm{ZnO}$ - Europium oxide doped Zinc oxide), TDM (Dy $\mathrm{MoO}_{4}$ - Dysprosium molybdate doped Zinc oxide), TGM ( $\mathrm{GdMoO}_{4} / \mathrm{ZnO}$ - Gadolinium molybdate doped Zinc oxide), TDV (DyVO $4^{-}$Dysprosium vanadate doped Zinc oxide), $\mathrm{TGV}\left(\mathrm{GdVO}_{4} / \mathrm{ZnO}-\right.$ Gadolinium vanadate doped Zinc oxide), THV $\left(\mathrm{HOVO}_{4} / \mathrm{ZnO}\right.$ - Holmium vanadate doped Zinc oxide), TGT ( $\mathrm{GdWO}_{4} / \mathrm{ZnO}$ - Gadolinium tungstate doped Zinc oxide), TDT $\left(\right.$ DyWO$_{6} / \mathrm{ZnO}$ - Dysprosium tungstate doped Zinc oxide), TZN (Commercial ZnO), THT 
$\left(\mathrm{HO}_{2} \mathrm{WO}_{6}\right.$ - Holmium tungstate doped Zinc oxide) against Bacillus brevis, (Gram positive) and E. coli, (Gram negative). One of the important application nanoparticles is to control the microbial contaminants in food, water (as a potential safety measure in food preservation) and in medicine and to understand the influence of the ENPs once discharged to environment especially on the natural microbes. This study paves the way for the use of the engineered nanoparticles (ENPs) against the microorganisms in the field of medicine, food packaging, water treatment and anti-coating agents.

\section{EXPERIMENTAL SETUP}

\section{A. Preparation of engineered nano materials}

The characterization and procedure of engineered nanoparticles preparation are described in our earlier papers (Thirumalai et al., 2017). Distilled water was used as solvent to dissolve $100 \mathrm{mg} / \mathrm{ml}$ of prepared nanoparticles. This sample was then mixed gently before inoculating into well for proper dispersion of nanoparticles in the distilled water. The naming and category of different nanoparticles are given in Table 1.

\section{B. Antibacterial activity by well diffusion method}

Overnight culture of Bacillus brevis and E. coli $(100 \mu \mathrm{L})$ were swabbed on the surface of Luria-Bertani agar (Becton Dickinson) prepared using nutrient agar medium. For $10 \mathrm{~min}$ the plates were the kept to dry before the well punch. The antimicrobial activities were determined by modified agar well diffusion method (Heatley, 1994). Approximately $5 \mathrm{~mm}$ well was made by using a cork borer and $40 \mu \mathrm{L}$ of the test sample was poured into the wells. The plates were then incubated at $37^{\circ} \mathrm{C}$ for 24 hours. A standard millimeter scale or by a vernier caliper scale was used to measure the diameter of the zone of inhibition as indicated by the clear area which was devoid of growth of microbes (Magaldi et al., 2004; Valgas et al., 2007). All the antibacterial tests were carried out in triplicate and the average is reported.

\section{Statistical Analysis}

All the experiments were performed under controlled conditions and with appropriate controls. Each experiment was carried out in triplicates and the data are expressed as mean \pm standard deviation. To define statistically significant differences, the data are analyzed with one-way analysis of variance ANOVA assuming equal variances at $\mathrm{p}<0.01$.

\section{RESULT AND DISCUSSION}

To our knowledge this is the first study showing the effect of novel engineered tri metallic nanoparticles with significant antibacterial properties. Using well diffusion method, the antibacterial activity of the prepared 17 engineered nanoparticles against Bacillus brevis (gram positive) and E. coli (gram negative) bacteria was tested. Fig. 1 shows the Clear zones of inhibition of respective engineered nanoparticle (in various plate cultures) against gram positive and gram negative bacteria as seen in Fig. 1. All the values mentioned for zones of inhibition are in $\mathrm{mm}$ scale. Fig. 2 shows the comparison of antibacterial activity of the 17 nanoparticles against Bacillus brevis and E. coli.

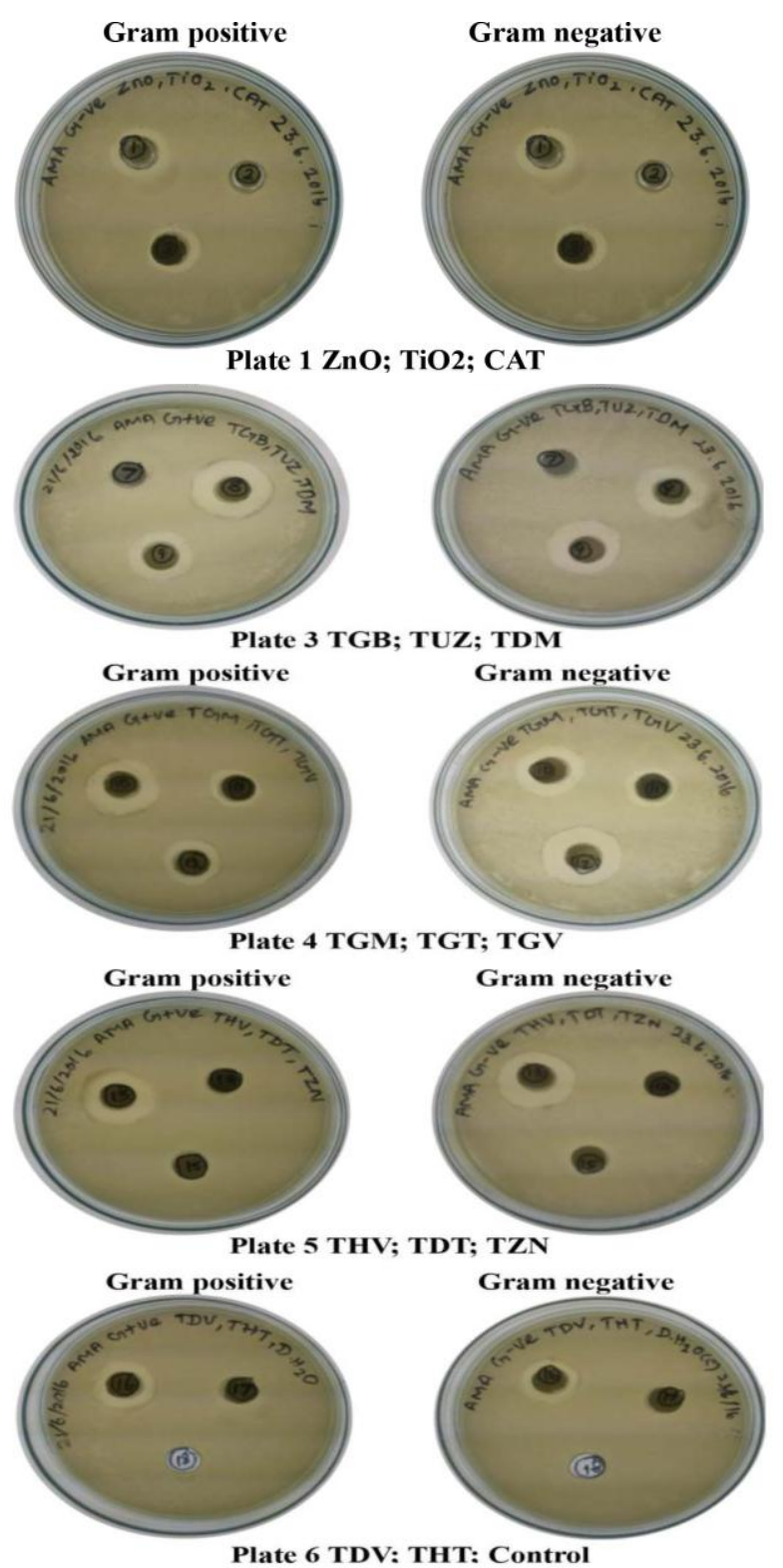

Figure: 1 Inhibition zone comparison of Bacillus brevis (Gram +ve) and $E$. coli (Gram -ve)

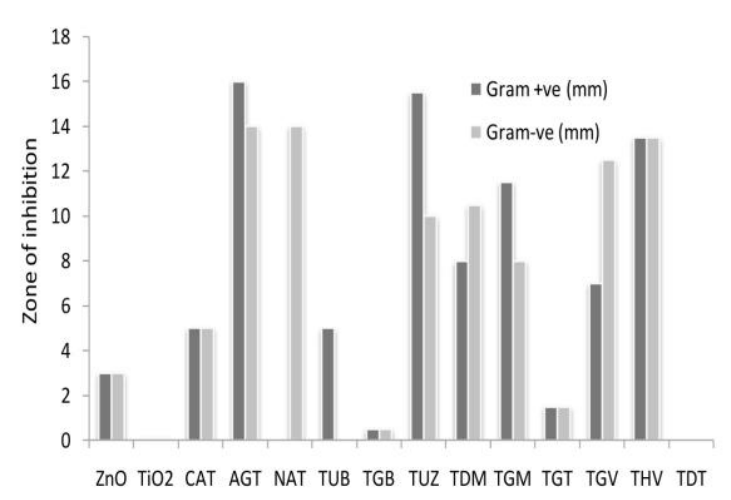

Figure: 2 Comparison of antibacterial activity of synthesized nanoparticle

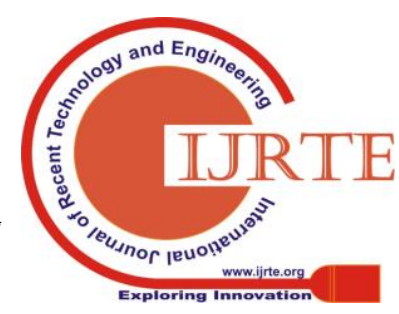


Table 1 Naming and Category of different nanoparticles investigated.

\begin{tabular}{|c|c|c|c|}
\hline $\begin{array}{l}\text { S. } \\
\text { No }\end{array}$ & $\begin{array}{l}\text { Nanoparticle } \\
\text { (acronym) }\end{array}$ & $\begin{array}{l}\text { Nanoparticle - } \\
\text { Full name }\end{array}$ & Category \\
\hline 1 & $\mathrm{ZnO}$ & Zinc Oxide & $\begin{array}{l}\text { Metal Oxide - } \\
\text { Undoped }\end{array}$ \\
\hline 2 & $\mathrm{TiO}_{2}$ & Titanium Oxide & $\begin{array}{l}\text { Metal Oxide - } \\
\text { Undoped }\end{array}$ \\
\hline 3 & AGT $\left(\mathrm{Ag} / \mathrm{TiO}_{2}\right)$ & $\begin{array}{l}\text { Silver Titanium } \\
\text { Oxide }\end{array}$ & $\begin{array}{l}\text { Dimetalic Oxide } \\
\text { - Doped }\end{array}$ \\
\hline 4 & $\begin{array}{l}\text { CAT } \\
\left(\mathrm{Cd} / \mathrm{Ag} / \mathrm{TiO}_{2}\right)\end{array}$ & $\begin{array}{l}\text { Cadmium } \\
\text { Silver Titanium } \\
\text { Oxide }\end{array}$ & $\begin{array}{l}\text { Trimetalic Oxide } \\
\text { - Doped }\end{array}$ \\
\hline 5 & $\begin{array}{l}\text { NAT } \\
\left(\mathrm{Ni} / \mathrm{Ag} / \mathrm{TiO}_{2}\right)\end{array}$ & $\begin{array}{l}\text { Nickel Silver } \\
\text { Titanium Oxide }\end{array}$ & $\begin{array}{l}\text { Trimetalic Oxide } \\
\text { - Doped }\end{array}$ \\
\hline 6 & $\begin{array}{l}\text { TUB (Bare } \\
\left.\mathrm{Eu}_{2} \mathrm{O}_{3}\right)\end{array}$ & $\begin{array}{l}\text { Europium } \\
\text { oxide }\end{array}$ & $\begin{array}{l}\text { Metal Oxide - } \\
\text { Undoped }\end{array}$ \\
\hline 7 & $\begin{array}{l}\text { TGB (Bare } \\
\left.\mathrm{Gd}_{2} \mathrm{O}_{3}\right)\end{array}$ & Gadolinium & $\begin{array}{l}\text { Metal Oxide - } \\
\text { Undoped }\end{array}$ \\
\hline 8 & $\begin{array}{l}\text { TUZ } \\
\left(\mathrm{Eu}_{2} \mathrm{O}_{3} / \mathrm{ZnO}\right)\end{array}$ & $\begin{array}{l}\text { Europium } \\
\text { oxide doped } \\
\text { Zinc oxide }\end{array}$ & $\begin{array}{l}\text { Dimetalic Oxide } \\
\text { - Doped }\end{array}$ \\
\hline 9 & $\begin{array}{l}\text { TDM (Dy } \\
\left.\mathrm{MoO}_{4}\right)\end{array}$ & $\begin{array}{l}\text { Dysprosium } \\
\text { molybdate } \\
\text { doped Zinc } \\
\text { oxide }\end{array}$ & $\begin{array}{l}\text { Trimetalic Oxide } \\
\text { - Doped }\end{array}$ \\
\hline 10 & $\begin{array}{l}\text { TGM } \\
\left(\mathrm{GdMoO}_{4} / \mathrm{ZnO}\right)\end{array}$ & $\begin{array}{l}\text { Gadolinium } \\
\text { molybdate } \\
\text { doped Zinc } \\
\text { oxide }\end{array}$ & $\begin{array}{l}\text { Trimetalic Oxide } \\
\text { - Doped }\end{array}$ \\
\hline 11 & $\mathrm{TDV}\left(\mathrm{DyVO}_{4}\right)$ & $\begin{array}{l}\text { Dysprosium } \\
\text { vanadate doped } \\
\text { Zinc oxide }\end{array}$ & $\begin{array}{l}\text { Trimetalic Oxide } \\
\text { - Doped }\end{array}$ \\
\hline 12 & $\begin{array}{l}\text { TGV } \\
\left(\mathrm{GdVO}_{4} / \mathrm{ZnO}\right)\end{array}$ & $\begin{array}{l}\text { Gadolinium } \\
\text { vanadate doped } \\
\text { Zinc oxide }\end{array}$ & $\begin{array}{l}\text { Trimetalic Oxide } \\
\text { - Doped }\end{array}$ \\
\hline 13 & $\begin{array}{l}\text { THV } \\
\left(\mathrm{HOVO}_{4} / \mathrm{ZnO}\right)\end{array}$ & $\begin{array}{l}\text { Holmium } \\
\text { vanadate doped } \\
\text { Zinc oxide }\end{array}$ & $\begin{array}{l}\text { Trimetalic Oxide } \\
\text { - Doped }\end{array}$ \\
\hline 14 & $\begin{array}{l}\text { TGT } \\
\left(\mathrm{GdWO}_{4} / \mathrm{ZnO}\right)\end{array}$ & $\begin{array}{l}\text { Gadolinium } \\
\text { tungstate doped } \\
\text { Zinc oxide }\end{array}$ & $\begin{array}{l}\text { Trimetalic Oxide } \\
\text { - Doped }\end{array}$ \\
\hline 15 & $\begin{array}{l}\text { TDT } \\
\left(\mathrm{DyWO}_{6} / \mathrm{ZnO}\right)\end{array}$ & $\begin{array}{l}\text { Dysprosium } \\
\text { tungstate doped } \\
\text { Zinc oxide }\end{array}$ & $\begin{array}{l}\text { Trimetalic Oxide } \\
\text { - Doped }\end{array}$ \\
\hline 16 & $\mathrm{TZN}$ & $\begin{array}{l}\text { Commercial } \\
\mathrm{ZnO}\end{array}$ & $\begin{array}{l}\text { Metal Oxide - } \\
\text { Undoped }\end{array}$ \\
\hline 17 & $\begin{array}{l}\text { THT } \\
\left(\mathrm{HO}_{2} \mathrm{WO}_{6}\right)\end{array}$ & $\begin{array}{l}\text { Holmium } \\
\text { tungstate doped } \\
\text { Zinc oxide }\end{array}$ & $\begin{array}{l}\text { Trimetalic Oxide } \\
\text { - Doped }\end{array}$ \\
\hline
\end{tabular}

The zone of inhibition values ( $\mathrm{mm}$ ) are summarized in Table 2. For gram positive Bacillus brevis, the nano particle shows high antibacterial activity in the order of AGT>TUZ> THV $>$ TGM $>$ TDV $>$ TDM $>$ TGV $>$ TUB; CAT $>$ ZnO $>$ TGT $>$ TGB> $\mathrm{TiO}_{2}$; TZN; THT. Further TDT and NAT showed no activity. For gram negative $E$. coli, the nano particle shows high antibacterial activity in the order of AGT; $\mathrm{NAT}>\mathrm{THV}>\mathrm{TGV}>\mathrm{TDV}$; $\mathrm{TDM}>\mathrm{TUZ}>\mathrm{TGM}>\mathrm{CAT}>\mathrm{ZnO}>$ TGT> TGB $>\mathrm{TiO}_{2}$; TZN; THT, while TUB and TDT, were found to show no inhibition.
Table 2 Zone of inhibition $(\mathrm{mm})$ by the nanoparticle in gram positive and gram negative bacteria.

\begin{tabular}{|l|l|l|}
\hline $\begin{array}{l}\text { Nano } \\
\text { particle }\end{array}$ & $\begin{array}{l}\text { Gram positive } \\
(\mathbf{m m})\end{array}$ & $\begin{array}{l}\text { Gram negative } \\
(\mathbf{m m})\end{array}$ \\
\hline $\mathrm{ZnO}$ & 3 & 3 \\
\hline $\mathrm{TiO}_{2}$ & 0.1 & 0.1 \\
\hline $\mathrm{CAT}$ & 5 & 5 \\
\hline AGT & 16.0 & 14 \\
\hline NAT & 0 & 14 \\
\hline TUB & 5 & 0 \\
\hline TGB & 0.5 & 0.5 \\
\hline TUZ & 15.5 & 10.0 \\
\hline TDM & 8 & 10.5 \\
\hline TGM & 11.5 & 8.0 \\
\hline TGT & 1.5 & 1.5 \\
\hline TGV & 7 & 12.5 \\
\hline THV & 13.5 & 13.5 \\
\hline TDT & 0 & 0 \\
\hline TZN & 0.1 & 0.1 \\
\hline TDV & 10.5 & 10.5 \\
\hline THT & 0.1 & 0.1 \\
\hline
\end{tabular}

A.Effect of $\mathrm{ZnO} \mathrm{TiO}_{2}$ and $\mathrm{CAT}$

The effect of bactericidal activity of the prepared nano particles was recorded. Plate 1 demonstrated that $\mathrm{ZnO}$ and CAT nano particles inhibited both the E. coli and Bacillus brevis growth effectively. The zone of inhibition in $\mathrm{ZnO}$ was

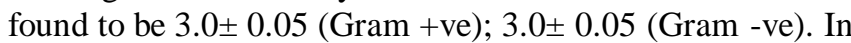
$\mathrm{TiO}_{2}$ it was found to be $0.1 \pm 0.05(\mathrm{Gram}+\mathrm{ve}) 0.1 \pm 0.05$ (Gram -ve). Whereas in CAT it was found to be $5.0 \pm 0.05$ $($ Gram +ve); $5.0 \pm 0.05$ (Gram -ve) respectively in Table 2. These results are correlated by the findings of Amna et al., (2015). Alhadrami \& Al-Hazmi (2017); Salehi et al., (2014) using zinc oxide, titanium oxide, cadmium. $\mathrm{ZnO}$ and $\mathrm{TiO}_{2}$ shows good antibacterial activity which has been previously reported by Amna, (2015); Yanping, (2011); Alhadrami \& Al-Hazmi, (2017). Jayaseelan et al (2012) have showed excellent anti-microbial effect of $\mathrm{ZnO}$ nano particles due to its important properties such as hydrophilicity, uniform water dispersion and stability (Jayaseelan et al., 2012). The bactericidal properties of $\mathrm{TiO}_{2}$ nanoparticles can be explained by its stability and oxidative attack on outer/inner cell wall membrane (Sarah et al., 2013; Fidel et al., 2010). In our study also $\mathrm{ZnO}$ and $\mathrm{TiO}_{2}$ has been proved to be an effective microbial inhibitor. The combination of cadmium silver titanium oxide, however shows good antibacterial effect. The antibacterial effect of cadmium was very well studied by Salehi et al. (2015); Salehi et al. (2014) Hence it is very well understood that the addition of cadmium along with silver and titanium oxide shows good antibacterial activity.

\section{B. Effect of AGT, NAT and TUB}

AGT and NAT nano particles inhibited both the E. coli and Bacillus brevis growth effectively (Plate 2). The zone of

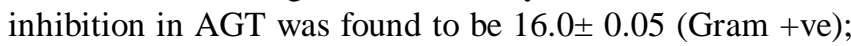
$14.0 \pm 0.05$ (Gram -ve), whereas in NAT it was found to be $14.0 \pm 0.05$ (Gram -ve) and no effect in Gram positive. And for TUB it was found to be $5.0 \pm$ 0.05 (Gram +ve) and no effect in Gram negative (Table 2). Joanna 
et al., (2014) also reported in their study that europium ions do not show any bactericidal effect on $E$. coli.

The antibacterial effect of $\mathrm{Ag}$ and $\mathrm{TiO}_{2}$ have been reported separately by Ming et al., (2015) Besinis et al. (2014); Fidel et al. (2010). Further Ag and TiO2 combinations by Lopez et al. (2012). In this study it was found that $\mathrm{TiO}_{2}$ itself showed less significant microbial inhibition but when combined with $\mathrm{Ag}$ in AGT, the antimicrobial property was found to increase by several folds (Lopez et al., 2012). This is due to the release of Ag ions from AGT which binds with DNA decreasing its replication activity; also certain cellular proteins become deactivated on binding with Ag ions (Guzman et al., 2012). According to Morteza et al. (2017); Ashtari et al. (2014) the nickel nanoparticles have best antimicrobial properties. In this study, the Ni nanoparticles were combined with $\mathrm{Ag}$ and $\mathrm{TiO}_{2}$ Therefore a significant bactericidal effect was found on $E$. coli (inhibition zone $10.0 \mathrm{~mm}$ ) while Bacillus sp., was not influenced in presence of NAT. Similarly, TUB showed no activity on gram negative, Joanna et al. (2014) study also says that europium doesn't show bactericidal activity. But TUB shows some antibacterial effect in gram positive bacteria.

\section{Effect of TGB, TUZ and TDM}

TUZ and TDM nanoparticles inhibited both the E. coli and Bacillus brevis growth effectually (Plate 3) (Gram -ve). In TGB the zone of inhibition was found to be $0.5 \pm 0.05$ (Gram +ve); $0.5 \pm 0.05$ (Gram -ve). In TUZ the zone of inhibition was found to be $15.5 \pm 0.05(\mathrm{Gram}+\mathrm{ve}) ; 10.0 \pm$ 0.05 (Gram -ve) and the zone of inhibition in TDM was found to be $8.0 \pm 0.05(\mathrm{Gram}+\mathrm{ve}) ; 10.5 \pm 0.05$ (Gram -ve) respectively in Table 2 .

As europium doesn't have any antibacterial properties (Joanna et al., 2014), the combination of europium with zinc oxide TUZ shows high antibacterial effect. Also Dysprosium (Moradi et al., 2017), Molybdate (Meng and Xiong 2008) Zinc oxide (Pawan et al., 2017) itself has their antimicrobial properties. Hence by the combination of all the three TDM (Dysprosium Molybdate doped Zinc oxide) shows good antibacterial properties. TGB Bare Gadolinium itself shows minor antibacterial effect on both gram positive and negative microbes. According to Franchini et al. (2012) and Valappil et al. (2009) exchanges of ions during protein metabolism in the microbial cells in presence of gallium ions brings about the antibacterial activity.

\section{Effect of TGM, TGT and TGV}

TGM, TGT and TGV nanoparticles inhibited both the E. coli and Bacillus brevis growth (Plate 4). The zone of inhibition in TGM was found to $11.5 \pm 0.05(\mathrm{Gram}+\mathrm{ve})$; $8.0 \pm$ 0.05 (Gram -ve); In TGT the zone of inhibition was found to be $1.5 \pm 0.05(\mathrm{Gram}+\mathrm{ve}) ; 1.5 \pm 0.05$ (Gram -ve); In TGV the zone of inhibition was found to be $7.0 \pm 0.05(\mathrm{Gram}+\mathrm{ve})$; $12.5 \pm 0.05$ (Gram -ve) respectively in Table 2 .

The combination Gadoinium along with molybdate and zinc oxide, TGM (Gadolinium molybdate doped zinc oxide) But the combination of tungstate with gadolinium (TGTGadolinium tungstate doped zinc oxide) shows minor activity. There are several reference for combination of metal oxide in anti-microbial properties. The antibacterial activity of combination of Gadolinium with cerium were reported by Syed et al. (2017). As well as Gadolinium with samarium oxide and erbium oxide were already reported by Dedkova et al. (2017).

\section{E. Effect of THV, TDT and TZN}

THV nanoparticle inhibited both the E. coli and Bacillus growth (Plate 5). The zone of inhibition in THV was found to $13.5 \pm 0.05$ (Gram +ve); 13.5 0.05 (Gram -ve). Whereas the zone of inhibition in TZN was found to $0.1 \pm 0.05$ (Gram +ve); $0.1 \pm 0.05$ (Gram -ve). TDT showed no activity (Table 2).

The combination of vanadate with holmium THV (Tungstate holmium vanadate) shows good activity. But with Dysprosium (TDT-Dysprosium tungstate doped zinc oxide) it doesn't show any bactericidal effect. Tungstate (Moodi et al., 2012) and dysprosium metal (Raffi et al., 2008) individually were able to produce antibacterial properties. But when came into mixture it fails to produce bactericidal effect. TZN (zinc oxide) shows minor antibacterial properties (Jayaseelan et al., 2012).

\section{F. Effect of TDV, THT and Control}

TDV nanoparticle inhibited the microbial growth effectively (Plate 6). The zone of inhibition in TDV was found to $10.5 \pm 0.05(\mathrm{Gram}+\mathrm{ve}) ; 10.5 \pm 0.05$ (Gram -ve). The antibacterial effect for combination of vanadate with compounds like Dysprosium TDV were already studied by Syed et al. (2010) and Moodi et al. (2012). The combination of Holmium with tungstate (THT-Holmium tungstate doped zinc oxide) shows no activity.

By comparing all the different nanoparticles, AGT $\left(\mathrm{Ag} / \mathrm{TiO}_{2}-\right.$ Silver Titanium Oxide) shows high antibacterial activity against gram positive and gram negative bacteria. The inhibitory action of silver nanoparticles is higher amongst all nano semiconductor oxides tested. This is because the silver ions degrade the bacteria by interacting with the nucleic acid and thereby stop the DNA repletion (Raffi 2008). According to Lee et al. (2007) silver ions bind with the protein molecule and inhibit the cellular metabolism and causes death to the microorganism.

One-way ANOVA results show that the zone of inhibition formed between gram positive and gram negative are significantly different. The level of significance is obtained as $* \mathrm{p}<0.05$.

\section{CONCLUSION}

The antibacterial effect of Nano particle has been studied to know its applications in biomedicine, pharmaceuticals, food industry etc., The Nanoparticle possess unique properties and excellent stability for acting as a novel antibacterial agent. The achieved data revealed that the synthesized nano particles have potential antibacterial property. Comparing all the 17 nano particles AGT $\left(\mathrm{Ag} / \mathrm{TiO}_{2}\right)$ showed high antibacterial activity just by incorporating $\mathrm{Ag}$ antibacterial agent. The interaction of silver ions with the cellular component is the basic mode of action of the antibacterial properties of the nanoparticles. Those silver ions adhere the cell wall and penetrate through the cell membrane and inhibit the bacterial growth. Hence $\mathrm{Ag} / \mathrm{TiO}_{2}$ develop multidrug resistant against microorganism and act as a substitute to antibiotics. 


\section{REFERENCES}

1. S. K. Sahoo, S. Parveen, and J. J. Panda, "The present and future of nanotechnology in human health care," Nanomedicine, 2007, pp. 3(1), 20-31.

2. O. M. Koo, I. Rubinstein, and H. Onyuksel, "Role of nanotechnology in targeted drug delivery and imaging: a concise review," Nanomedicine, 2005, pp. 1(3), 193-212.

3. G. T. M. Lopez, L. M. A. Alvarez, V. A. Morales, E. G. Lopez, and P. C. Ocampo, "Study of Bacterial Sensitivity to $\mathrm{Ag}-\mathrm{TiO}_{2}$ Nanoparticles," Journal of Nanomedicine \& Nanotechnology, 2012, pp. S5, (003), 1-7.

4. I. Brigger, C. Dubernet, and P. Couvreur, "Nanoparticles in cancer therapy and diagnosis," Advanced Drug Delivery Reviews, 2002, pp. 54(5), 631-651.

5. X. Wu, H. Liu, J. Liu, K. N. Haley, J. A. Treadway, J. P. Larson, E. Ge, F. Peale, and M. P. Bruchez, "Immunofluorescent labelling of cancer marker Her2 and other cellular targets with semiconductor quantum dots," Nature Biotechnology, 2003, pp. 21(1), 41-46.

6. G. Pattan, and G. Kaul, "Health hazards associated with nanomaterials," Toxicology \& Industrial Health, 2014, pp. 30(6), 499-519.

7. M. Swaminathan, and K. S. Naresh, "Antimicrobial Activity of the Engineered Nanoparticles used as Coating Agents," Handbook of Ecomaterials, 2017, pp. 1-15.

8. R. Wahab, A. Mishra, S. I. Yun, Y. S. Kim, and H. S. Shin, “Antibacterial activity of $\mathrm{ZnO}$ nanoparticles prepared via non-hydrolytic solution route," Applied Microbiology and Biotechnology, 2010, pp. 87(5), 1917-1925.

9. P. K. Stoimenov, R. L. Klinger, G. Marchin, and K. J. Klabunde, "Metal oxide nanoparticles as bactericidal agents," Langmuir, 2002, pp. 18(17), 6679-6686.

10. C. M. Sarah, S. R. Suprakas, S. O. Maurice, N. B. Maggie, and D. S. T. Mombaca, "Microwave-assisted synthesis, characterization and antibacterial activity of $\mathrm{Ag} / \mathrm{ZnO}$ nanoparticles supported bentonite clay,' Journal of Hazardous Materials, 2013, pp. 262, 439-446.

11. G. R. Rajiv, S. Gowri, J. Suresh, and M. Sundrarajan, "Ionic Liquids Assisted Synthesis of ZnO Nanostructures: Controlled Size, Morphology and Antibacterial Properties," Journal of Materials Science \& Technology, 2013, pp. 29(6), 533-538.

12. L. Xiaoyan, L. Yan, W. Tao, and H. Jianguo, "Antibacterial activity of hierarchical nanofibrous titania-carbon composite material deposited with silver nanoparticles," New Journal of Chemistry, 2012, pp. 36, 2568-2573.

13. Z. Yanjing, W. Zuoshan, C. Jialei, Z. Xiufeng, and L. Juan, "Synthesis of $\mathrm{ZnO} / \mathrm{CaF}_{2}$ nano composites with good antibacterial property and poor photocatalytic activity," Materials Letters, 2013, pp. 108, 103-105.

14. A. Stoyanova, H. Hitkova, and A. Bachvarova-Nedelcheva, "Synthesis and antibacterial activity of $\mathrm{TIO}_{2} / \mathrm{ZnO}$ nanocomposites Prepared via non hydrolytic route," Journal of Chemical Technology and Metallurgy, 2013, pp. 48(2), 154-161.

15. V. Jaskova, H. Libuse, and V. Jarmila, “ $\mathrm{TiO}_{2}$ and $\mathrm{ZnO}$ Nanoparticles in Photocatalytic and Hygienic Coatings," International Journal of Photoenerg., 2013, pp.795060, 1-6.

16. A. Travan, E. Marsich, and I. Donati, "Silver-polysaccharide nanocomposite antimicrobial coatings for methacrylic thermosets," Acta. Biomaterialia., 2011, pp. 7(1), 337-346.

17. J. T. Seil, and T. J. Webster, "Antimicrobial applications of nanotechnology: methods and literature," International Journal of Nanomedicine, 2012, pp. (7), 2767-2781.

18. N. Sobana, M. Muruganadham, and M. Swaminathan, "Nano-Ag particles doped $\mathrm{TiO}_{2}$ for efficient photo degradation of Direct azo dyes," Journal of Molecular Catalysis A: Chemical, 2006, pp. 258, 124-132.

19. K. Thirumalai, S. Balachandran, M. Shanthi, and M. Swaminathan, "Hetero structured dysprosium vanadate $-\mathrm{ZnO}$ for photo-electrocatalytic and self-cleaning applications," Materials Science in Semiconductor Processing, 2017, pp. 71, 84-92.

20. K. Thirumalai, M. Shanthi, and M. Swaminahan, "Natural sunlight active $\mathrm{GdVO}_{4}-\mathrm{ZnO}$ nanomaterials for photo-electrocatalytic and self-cleaning applications," Journal of Water Process Engineering, 2017, pp. 17, 149-160.

21. N. G. Heatley, "A method for the assay of penicillin," Biochemical Journal, 1994 pp 38(1): 61-65.

22. S. Magaldi, S. Mata-Essayag, and C. Hartung, "Well diffusion for antifungal susceptibility testing," International Journal of Infectious Diseases, 2004, pp. 8(1), 39-45.
23. C. Valgas, S. M. De Souza, and E. F. A. Smania, "Screening methods to determine antibacterial activity of natural products," Brazilian Journal of Microbiology, 2007, pp. 38(2), 369-380.

24. S. Amna, M. Shahrom, S. Azman, H. M. K. Noor, C. A. Ling, K. M. B Siti, H. Habsah, and M. Dasmawati, "Review on zinc oxide nano particles: Antibacterial activity and toxicity mechanism," Nano-Micro Letters, 2015, pp. 7(3), 219-224.

25. H. A. Alhadrami, and F. Al-Hazmi, "Antibacterial Activities of Titanium Oxide Nanoparticles," Journal of Bioelectronics Nanotechnology, 2017, pp. 2(1), 1-5.

26. B. Salehi, S. Mehrabian, and M. Ahmadi, "Investigation of antibacterial effect of Cadmium Oxide nanoparticles on Staphylococcus aureus bacteria," Journal of Nanobiotechnology, 2014, pp. 12(26), 1-8.

27. B. Salehi, E. Mortaz, and P. Tabarsi, "Comparison of antibacterial activities of cadmium oxide nanoparticles against Pseudomonas aeruginosa and Staphylococcus aureus bacteria," Advanced Biomedical Research, 2015, pp. 4, 105.

28. X. Yanping, H. Yiping, L. I. Peter, J. Tony, and S. Xianming, "Antibacterial Activity and Mechanism of Action of Zinc Oxide Nanoparticles against Campylobacter jejuni," Applied and environmental microbiology, 2011, pp. 77(7), 2325-2331.

29. M. G. Fidel, L. O. Peggy, B. Adriana, O. Erasmo, N. Nereyda, M. S Elpidio, R. Facundo, B. Horacio, and A. G. Yossef, "Synthesis, characterization, and evaluation of antimicrobial and cytotoxic effect of silver and titanium nanoparticles," Nanomedicine, Nanotechnology, Biology and Medicine, 2010, pp. 6 (5), 681-688.

30. K. Joanna, G. Ewa, and K. R. Dagmara, "Substituted Hydroxyapatites with Antibacterial Properties," BioMed Research International, 2014, pp. $178123,1-15$

31. S. W. Ming, W. C. Chun, C. H. Chia, C. H. Shih, S. S. Der, and H. C. Hsin, "Antibacterial property of Ag nanoparticle-impregnated N-doped titania films under visible light," Scientific Reports, 2015, pp. 5, 11978. DOI: $10.1038 /$ srep1 1978 .

32. A. Besinis, T. De Peralta, and R. D. Handy, "The antibacterial effects of silver, titanium dioxide and silica dioxide nanoparticles compared to the dental disinfectant chlorhexidine on Streptococcus mutans using a suite of bioassays," Nanotoxicology, 2014, pp. 8(1), 1-16. doi:10.3109/ 17435390.2012.742935

33. M. Guzman, J. Dille, and S. Godet, "Synthesis and antibacterial of silver nanoparticles against gram-positive and gram negative bacteria," Nanomedicine: nanotechnology Biology and Medicine, 2012, pp. 8(1), 37-45.

34. V. Morteza, H. J. Nima, Y. Saber, and G. Marrryam, "Evolution of antibacterial effect of nickel nanoparticles on bioflim production by Staphylococcus epidermis, " Iranian Journal of Bio Microbiology, 2017, pp. 9(3), 160-168.

35. K. Ashtari, J. Fasihi, N. Mollania, and K. Khajeh, "Biotemplated nickel nanostructure; Synthesis, Characterization and antibacterial activity," Materials Research Bulletin, 2014, pp. 50, 348-353.

36. Z. Moradi, M. M. Khorasani, and M. Noroozifar, "Synthesis and biological evaluation of a new dysprosium (III) complex containing 2 , 9-dimethyl 1, 10-phenanthroline," Journal of Biomolecular Structure \& Dynamics, 2017, pp. 35 (2), 300-311.

37. Y. Y. Meng, and Z. X. Xiong, "Preparation of Molybdates with Antibacterial Property,” Key Engineering Materials, 2008, pp. 368 (372), 1516-1518.

38. K. M. Pawan, M. Harshita, E. Adam, T. Sushama, and V. Bhuvaneshwar, "Zinc oxide nanoparticles: a promising nanomaterial for biomedical applications," Drug Discovery Today 2017, pp. 22(12), 1825-1834.

39. M. Franchini, G. Lusvardi, G. Malavasi, and L. Menabue, "Gallium-containing phospho-silicate glasses: synthesis and in vitro bioactivity," Materials Science and Engineering: C Materials for Biological Applications, 2012, pp. 32(6), 1401-1406.

40. S. P. Valappil, D. Ready, and N. E. A. Abou, "Controlled delivery of antimicrobial gallium ions from phosphate-based glasses," Acta Biomaterialia, 2009, pp. 5(4), 1198-1210.

41. K. Y. A. Syed, A. Balamurugan, V. P. Devarajani, and R. Subramanian, "Hydrothermal Synthesis of Gadolinium (Gd) Doped Cerium Oxide $\left(\mathrm{CeO}_{2}\right)$ Nanoparticles: Characterization and Antibacterial Activity,' Oriental Journal of Chemistry, 2017, pp. 33(5), 2405-2411. 
42. K. Dedkova, L. Kuznikova, K. M. Pavelek, J. Kupkova, K. Cechbarabaszova, R. Vana, J. Burda, J. Vlcek, D. Cvejn, and J. Kukutschova, "Daylight induced antibacterial activity of gadolinium oxide, samarium oxide and erbium oxide nanoparticles and their aquatic toxicity," Materials Chemistry and Physics, 2017, pp. 197, 226-235.

43. M.A. Syed, U. Manzoor, I. Shah, and S. H. Bukhari, "Antibacterial effects of Tungsten nanoparticles on the Escherichia coli strains isolated from catheterized urinary tract infection (UTI) cases and Staphylococcus aureus," New Microbiologica., 2010, pp. 33(4): 329-335.

44. A. Moodi, M. M. Khorasani, M. Noroozifar, and S. Niroomand, "Binding analysis of ytterbium (III) complex containing 1, 10- phenanthroline with DNA and its antimicrobial activity," Journal of Biomolecular Structure and Dynamics, 2012, pp. 31(8), 937-950.

45. M. Raffi, F. Hussain, T. M. Bhatti, J. I. Akhter, A. Hameed, and M. M. Hasan, "Antibacterial characterization of silver nano particles against $E$. coil ATCC-1224," Journal of material science and technology, 2008, pp. 24 (2), 192-196.

46. C. Jayaseelan, R.A. Abdul, K. A. Vishnu, S. Marimuthua, T. Santhoshkumar, A. Bagavana, K. Gaurav, L. Karthik, R. and K. V. Bhaskara, "Novel microbial route to synthesize $\mathrm{ZnO}$ nanoparticles using Aeromonas hydrophila and their activity against pathogenic bacteria and fungi," Spectrochimica Acta Part A: Molecular and Biomolecular Spectroscopy, 2012, pp. 90, 78-84.

47. H. Y. Lee, H. K. Park, Y. M. Lee, K. Kim, and S. B. Park, "A practical procedure for producing silver nanocoated fabric and its antibacterial evaluation for biomedical applications," Chemical Communications, 2007, pp. 28(28), 2959-2961.

\section{AUTHORS PROFILE}

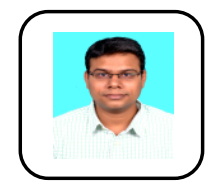

Naresh Kumar Sharma is an Associate Professor at Kalasalingam University in Department of Biotechnology. He completed his $\mathrm{PhD}$ from IIT Madras. His research interests include bioremediation and wastewater treatment.

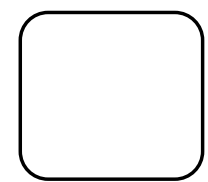

Balakrishnan A is a Summer Student's Visiting Internship Program at Kalasalingam University in Department of Biotechnology for the year 2017. His research interests include environmental engineering.

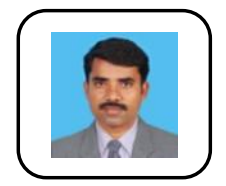

Dr. Kuppulingam Thirumalai currently works at the PG \& Research Department of Chemistry, Government Arts College, Thiruvannamalai, Tamilnadu, India. Dr.K.Thirumalai does research in Photochemistry, Electrochemistry, Nanotechnology and Materials

Chemistry.

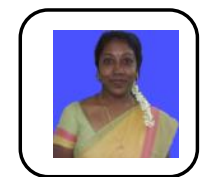

Karthika Arumugam completeed her $\mathrm{PhD}$ from Bhartidasan University, Tamilnadu. Her research includes solid waste management using vermicomposting. Currently she is working as an Assistant Professor in Department of Biotechnology at SFR Women College in Tamilnadu

Meenkashisundaram Swaminathan Professor at

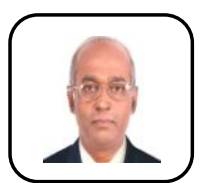
Annamalai University, Visiting Professor at Kalasalingam University has completed his PhD from IIT Kanpur. He has more than 200 publications to his credit with h-index and 110 index of 62 and 439 respectively. 